\title{
Factorial experimental design for the removal of disperse dyes using hydroxyapatite prepared from Moroccan phosphogypsum
}

\author{
Meryeme Joudi $^{1}$, Jihan Mouldar ${ }^{1}$, Houyem Hafdi ${ }^{1}$, Hamid Nasrellah ${ }^{1}$, badreddine Hatimi ${ }^{1}$, Moulay \\ Abderrahim El Mhammedi ${ }^{2}$, Mina Bakasse ${ }^{1, *}$ \\ ${ }^{1}$ Université Chouaib Doukkali, Faculté des Sciences, El Jadida, Maroc \\ ${ }^{2}$ Université Hassan $1^{\text {er }}$, Faculté Polydisciplinaire, Khouribga, Maroc
}

\begin{abstract}
Azo dyes are the major known group of synthetic dyes and have given rise to many water and soil environmental problems, most of these azo dyes were used in the textile industry. The aim of this study is the removal of Disperse Blue 79 (DB 79) and Disperse Blue 165 (DB 165) as azo dyes by Hydroxyapatite (HAP). The adsorption experiments were carried out to investigate the factors that influence the dyes uptake by hydroxyapatite, such as the contact time under agitation, adsorbent dosage, initial dye concentration, and $\mathrm{pH}$ solutions. To reduce the number of experiments, full factorial experimental design at two levels $\left(2^{4}\right)$ was used to achieve optimal conditions for the removal of DB 79 and DB 165 from aqueous solutions.
\end{abstract}

Keywords: Removal; Disperse Blue 79; Disperse Blue 165; Hydroxyapatite; Kinetics and isotherm study; Factorial experimental design.

\section{Introduction}

Azo dyes are widely used in textile and dyeing industries worldwide. The presence of these dyes at very low quantities in wastewater is highly visible and undesirable. However, it becomes toxic in the water bodies because of its complex molecular structure with multiple aromatic groups ${ }^{1}$ and because many of these dyes are made from known carcinogens, such as benzidine and other aromatic compounds.

The usual methods used for removing dyes from wastewater are flocculation ${ }^{2}$, coagulation ${ }^{3}$, precipitation ${ }^{4}$, adsorption ${ }^{5,6}$, electrochemical techniques ${ }^{7}$, ozonation ${ }^{8}$, membrane filtration ${ }^{9}$, and fungal decolorization ${ }^{10}$.

Adsorption is considered an attractive technique used for the removal of dyes from water. Many adsorbents were used to remove dyes, but hydroxyapatite (HAP) is an important inorganic material in chemistry and biology ${ }^{11}$, their ionic exchange property, adsorption affinity, and their ability to form bonds with organic molecules of different sizes, have given to this material the capability to attract different kinds of dyes.

The present study aimed to determine the optimum conditions for the removal of disperse dyes, DB 79 and DB 165 from aqueous solutions by synthesized hydroxyapatite from phosphogypsum. The factors that influence the dye uptake by the adsorbent were studied and optimized by Nemrodw (2000).

\section{Materials and methods}

\section{Reagents}

All chemicals used in the preparation and the adsorption studies were of analytical grade and used as received without further purification. Two different leather dyes (Disperse Blue 79 and Disperse Blue 165) were purchased from Sigma-Aldrich and carbosynth chemicals; the product number is 1223934-8 and 41642-51-7 respectively. The chemicals structures of these dyes are shown in Figure 1. 
(a)<smiles>COc1cc(N=Nc2c(Br)cc([N+](=O)[O-])cc2[N+](=O)[O-])c(NC=CCCNc2cc(OC)c([N+](=O)[O-])cc2Br)cc1C(C)=O</smiles>

(b)<smiles>CCCCN(CC)c1ccc(N=Nc2c(C#N)cc([N+](=O)[O-])cc2C#N)c(NC(C)=O)c1</smiles>

Figure 1. Chemical structure of (a) DB 79 and (b) DB 165.

\section{Preparation of HAP}

The phosphogypsum was treated using sulfuric acid $67 \%$, the obtained composite was washed by water, by acetone, dried at $65^{\circ} \mathrm{C}$ and the final anhydrite was sieving at $40 \mu \mathrm{m}^{12}$. The sieving anhydrite was mixed with phosphoric acid. The $\mathrm{pH}$ of the reaction was adjusted tobe 11 by adding Hydroxide sodium. After that, the produced HAP has been removed from the solution by filtration and the resulting powder was washed by water, dried at $80^{\circ} \mathrm{C}$ and $900^{\circ} \mathrm{C}^{13}$.

\section{Adsorption experiments}

All adsorption experiments were carried out in $150 \mathrm{~mL}$ Erlenmeyer flasks by mixing HAP with 100 $\mathrm{mL}$ of the dye solution at the desired operating conditions. Flasks were shaken in a stirrer (Velp scientifica) at $20^{\circ} \mathrm{C}$.

The dye solutions were stirrer along the time, and these were centrifuged at $4000 \mathrm{rpm}$. The supernatant was separated to measure the dyes concentration using JASCO V-630 spectrophotometer. For this measurement, the wavelengths of maximum absorption were 537 and $540 \mathrm{~nm}$ for DB 79 and DB 165 respectively.
The adsorption percentage $(\% \mathrm{Y})$ and adsorption capacity values at equilibrium, $\mathrm{qe}_{\mathrm{e}}\left(\mathrm{mg} \cdot \mathrm{g}^{-1}\right)$ and time $\mathrm{t}$, $\mathrm{q}_{\mathrm{t}}\left(\mathrm{mg} \cdot \mathrm{g}^{-1}\right)$ were calculated using the following equations:

$$
\begin{aligned}
& \% Y=\frac{C_{0}-C_{e}}{C_{0}} \times 100 \\
& q_{e}=\frac{C_{0}-C_{e}}{W} \times V \\
& q_{t}=\frac{C_{0}-C_{t}}{W} \times V
\end{aligned}
$$

Where $\mathrm{C}_{0}(\mathrm{mg} / \mathrm{L})$ is the initial dye concentration, $\mathrm{C}_{\mathrm{t}}$ is the dye concentration at time $(\mathrm{t}), \mathrm{C}_{\mathrm{e}}$ is the dye concentration at equilibrium, and $\mathrm{W}(\mathrm{g})$ is the HAP amount in the solution, $\mathrm{V}$ (l) is the volume.

\section{Experimental design and statistical analysis}

In order to study the effects of the various parameters, $2^{4}$ factorial experimentations were carried out, in two levels (low (-) and high (+)). The effects were designed as in Table 1 which shows the values of the factors selected in this study.

Table 1. Independent variables and levels used in this study.

\begin{tabular}{|ll|l|l|}
\hline \multicolumn{3}{|c|}{ Levels } \\
\hline Factors & Low $(-)$ & High $(+)$ \\
\hline $\mathbf{X}_{1}$ & Concentration $(\mathbf{m g} / \mathbf{L})$ & 20 & 100 \\
\hline $\mathbf{X}_{2}$ & Adsorbent Concentration $(\mathbf{g} / \mathbf{L})$ & 2 & 5 \\
\hline $\mathbf{X}_{3}$ & Size $(\boldsymbol{\mu m})$ & 125 & 200 \\
\hline $\mathbf{X}_{4}$ & Time $(\mathbf{m i n})$ & 5 & 40 \\
\hline
\end{tabular}

This factorial experimentation results in sixteen tests with all possible combinations of $X_{1}, X_{2}, X_{3}$ and $\mathrm{X}_{4}{ }^{14}$. Removal of DB 79 (\% $\left.\mathrm{Y}_{\mathrm{DB} 79}\right)$ and Removal of DB $165\left(\% Y_{\text {DB }} 165\right)$ were calculated for each of these tests as shown in Table 2.
The polynomial equation based on the first-order model with four factors $\left(\mathrm{X}_{1}, \mathrm{X}_{2}, \mathrm{X}_{3}\right.$ and $\left.\mathrm{X}_{4}\right)$ and all possible interactions was given in the form of the following expression:

$Y=b_{0}+b_{1} X_{1}+b_{2} X_{2}+b_{3} X_{3}+b_{4} X_{4}+b_{12} X_{1} X_{2}+b_{13} X_{1} X_{3}+b_{14} X_{1} X_{4}+b_{23} X_{2} X_{3}+b_{24} X_{2} X_{4}+b_{34} X_{3} X_{4}+b_{123} X_{1} X_{2} X_{3}$ $+b_{124} X_{1} X_{2} X_{4}+b_{134} X_{1} X_{3} X_{4}+b_{234} X_{2} X_{3} X_{4}+b_{1234} X_{1} X_{2} X_{3} X_{4}$

Where $b_{0}$ is the average value of the result; $b_{1}, b_{2}$, $b_{3}$ and $b_{4}$ are the linear coefficients; and $b_{12}, b_{13}, b_{14}$, $\mathrm{b}_{23}, \mathrm{~b}_{24}, \mathrm{~b}_{34}, \mathrm{~b}_{123}, \mathrm{~b}_{124}, \mathrm{~b}_{134}, \mathrm{~b}_{234}$ and $\mathrm{b}_{1234}$ represent the interactions coefficients. A total of sixteen experiments were analyzed using NEMRODW version $2000^{15}$. 
Table 2. Experimental design in term of factors and results of responses.

\begin{tabular}{|c|c|c|c|c|c|c|}
\hline & Concentratio & Adsorbent & Size & Time & \% Y DB79 & \% Y DB165 \\
\hline $\mathbf{1}$ & 20 & 2 & 125 & 5 & 62 & 30 \\
\hline $\mathbf{2}$ & 100 & 2 & 125 & 5 & 57 & 21 \\
\hline $\mathbf{3}$ & 20 & 5 & 125 & 5 & 89 & 75 \\
\hline $\mathbf{4}$ & 100 & 5 & 125 & 5 & 32 & 31 \\
\hline $\mathbf{6}$ & 20 & 2 & 200 & 5 & 58 & 19 \\
\hline $\mathbf{7}$ & 100 & 2 & 200 & 5 & 85 & 95 \\
\hline $\mathbf{8}$ & 20 & 5 & 200 & 5 & 59 & 52 \\
\hline $\mathbf{1 0}$ & 100 & 5 & 200 & 5 & 96 & 100 \\
\hline $\mathbf{1 1}$ & 20 & 2 & 125 & 40 & 62 & 28 \\
\hline $\mathbf{1 2}$ & 100 & 2 & 125 & 40 & 96 & 97 \\
\hline $\mathbf{1 3}$ & 20 & 5 & 125 & 40 & 94 & 98 \\
\hline $\mathbf{1 5}$ & 100 & 5 & 125 & 40 & 74 & 24 \\
\hline
\end{tabular}

\section{Results and Discussions}

\section{Characterization of HAP}
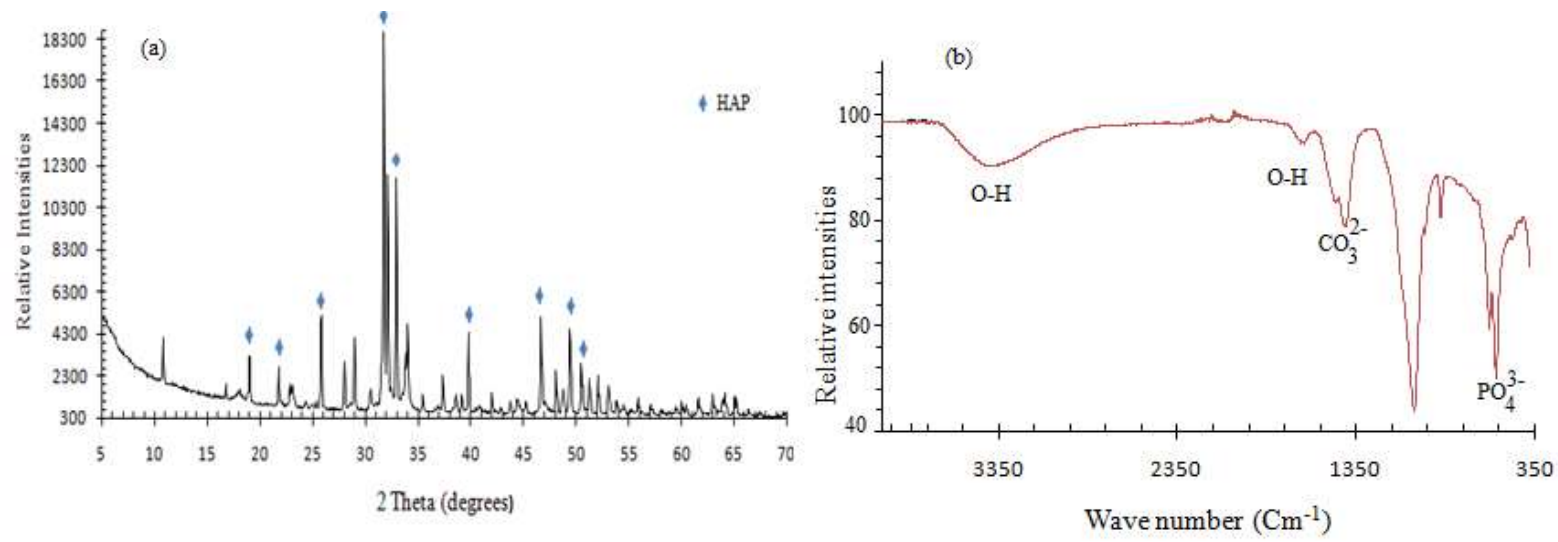

Figure 2. (a) XRD patterns and (b) FT-IR spectra of HAP.

Fig.2.a Shows XRD spectra of HAP, the formation of hydroxyapatite was indicated by characteristic peaks occurring at $2 \theta=25.9^{\circ}, 31.9^{\circ}$, $32.9^{\circ}$, and $34.1^{\circ}$, all diffraction peaks were indexed to pure hexagonal structural HAP (space group $\mathrm{P}_{3} / \mathrm{m}$ ) according to JCPDS card no. 09-043211.

Fig.2.b shows FTIR spectra of HAP, $\mathrm{PO}_{4^{3}}{ }^{-}$bands were registered from 500 to $600 \mathrm{~cm}^{-1}$, the bands assigned to the stretching modes of hydroxyl groups in hydroxyapatite were detected at $3560 \mathrm{~cm}^{-1}$, the stretching bands of $\mathrm{CO}_{3}{ }^{2-}$ have been reported at $1360 \mathrm{~cm}^{-1} 12$.
Study of the influence of factors on adsorption of DB 79 and DB 165 by HAP

The data obtained from the removal of DB 79 and DB 165by HAP (Table 2) suggested that assays 12 and 5 presented higher and lower adsorption removal of DB 79; however assays 9, 11, 15 and 6 presented higher and lower adsorption removal of DB 165.

\section{Data analysis}

Removal of DB 79

By combination between the different factors, $2^{4}$ experiences were listed in Table 2. The results obtained (Fig. 3) show that $\mathrm{X}_{1}$ (concentration of DB 79 ) and $X_{3}$ (size) have a negative effect on the 
$\mathrm{Y}_{1}$ (\% Removal of DB 79) response: decreasing the concentration of DB 79 and size of HAP (100-20 $\mathrm{mg} / \mathrm{L}$ and $200-125 \mu \mathrm{m}$, respectively) results in increase of the \% removal of DB 79. The adsorbent concentration of HAP effect is positive; the \% removal of DB 79 increases by increasing the adsorbent concentration, and this is due to the surface area available by more adsorbent particles ${ }^{16}$. The contact time is positive, the \% removal of DB 79 increases by increasing contact time. The interactions are represented graphically in Fig. 4 a, 4 b and 4c. The $\%$ removal of DB 79 increases by increasing the adsorbent concentration of HAP, contact time and by decreasing the initial DB 79 concentration and with $125 \mu \mathrm{m}$ in size of HAP.

$\begin{array}{lr}\text { Concentration of dye } & b 1 \\ \text { Adsorbent concentration } & b 2 \\ \text { Size } & b 3 \\ \text { Time } & b 4 \\ & b 12 \\ & b 13 \\ & b 23 \\ & b 14 \\ & b 24\end{array}$

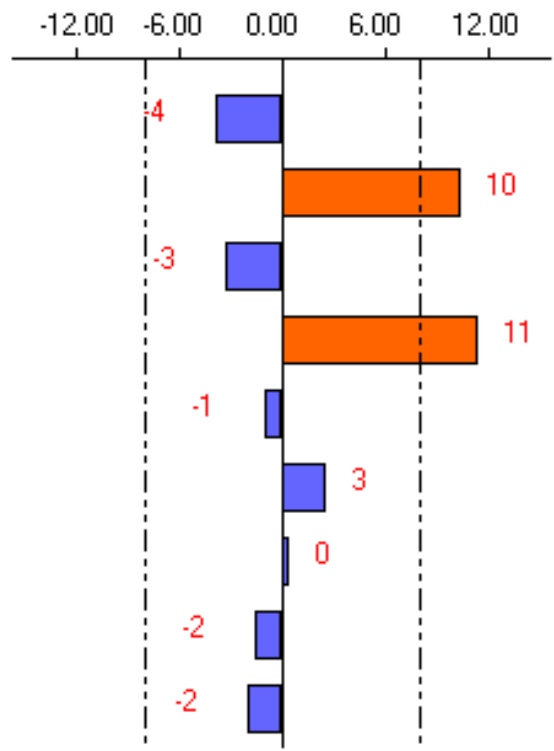

Figure 3. Values of the linear and quadratic coefficients for \% removal of DB 79

(a)

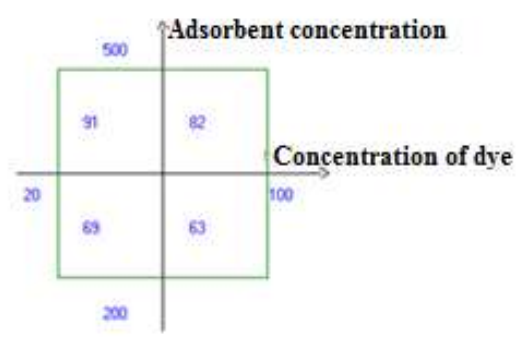

(b)

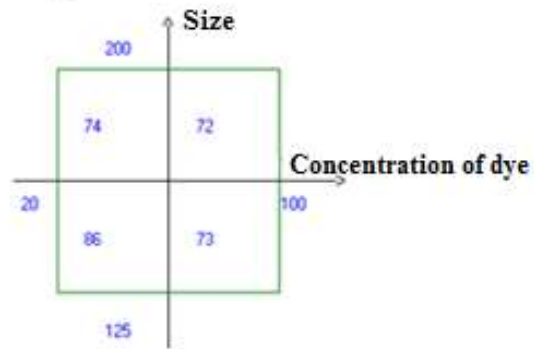

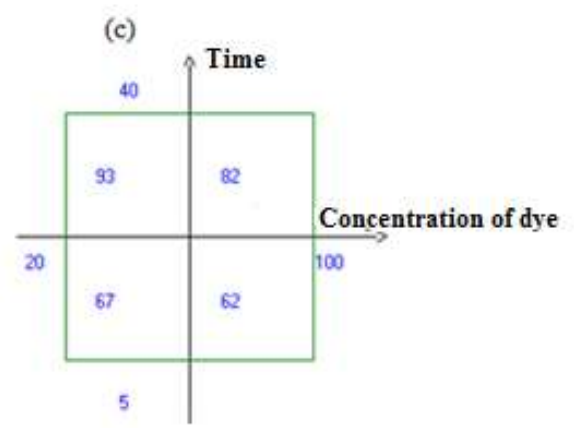

Figure 4. Interaction diagram for response Y1: Yield. (a) adsorbent concentration/Concentration DB 79, (b) Size/ Concentration DB 79 and (c) Time/ Concentration DB 79.

\section{Removal of DB 165}

The analysis of Fig. 5 shows that the $\mathrm{X}_{2}$ (adsorbent concentration), $\mathrm{X}_{3}$ (size) and $\mathrm{X}_{4}$ (time) have a positive effect of DB 165 removal, the \% removal of DB 165 increased by increasing adsorbent concentration, size of HAP and contact time, however the $\mathrm{X}_{1}$ (effect of dye concentration) has a negative effect of $\%$ DB 165 removal.

Figs. $6 \mathrm{a}, 6 \mathrm{~b}$ and $6 \mathrm{c}$ show the interaction between factors, the \% DB 165 removal increases by increasing adsorbent concentration, size and time, on the other hand, the removal efficiency increases by decreasing initial dye concentration. 


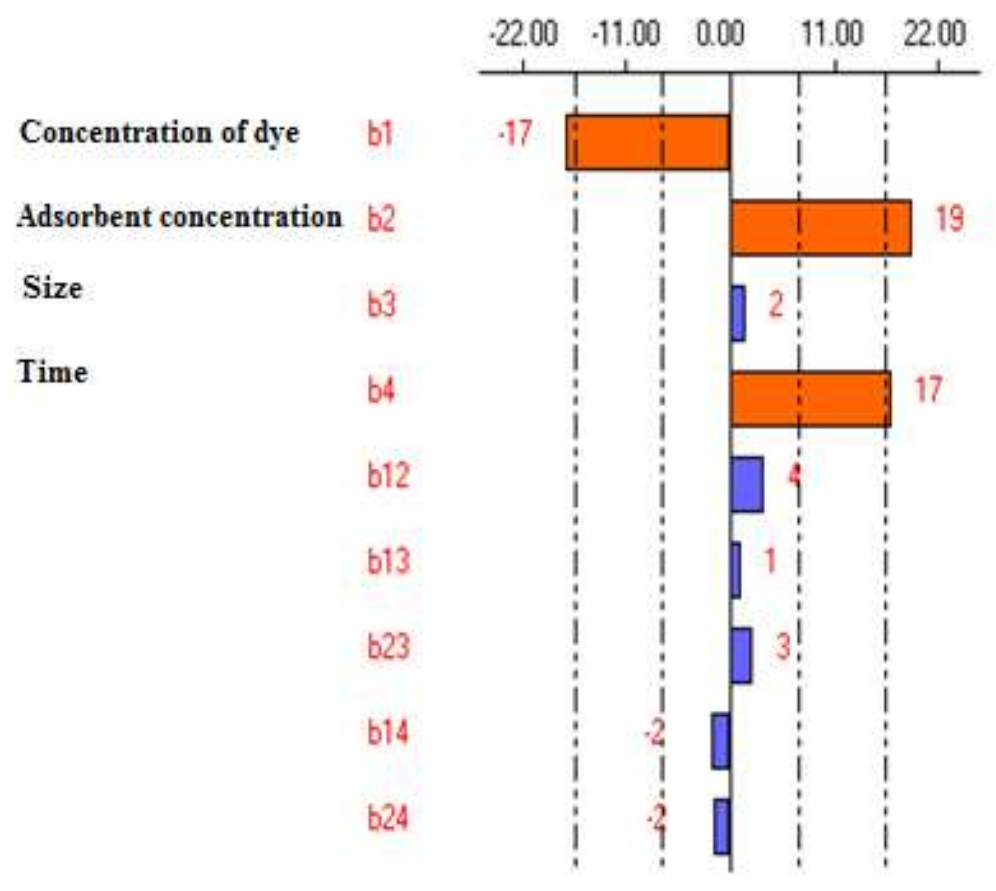

Figure 5. Values of the linear and quadratic coefficients for \% removal of DB 165
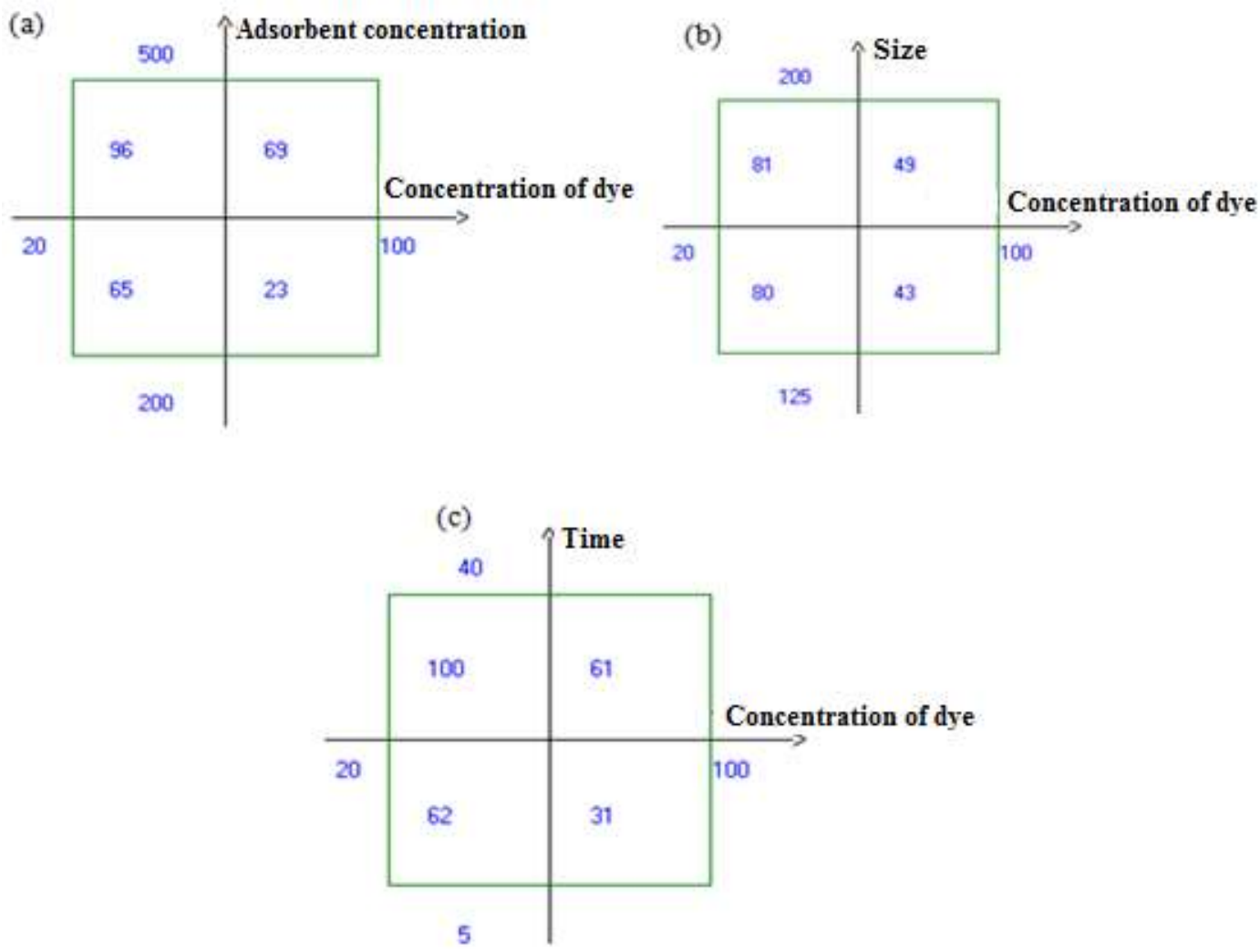

Figure 6. Interaction diagram for response Y2: Yield. (a) Adsorbent concentration/Concentration DB 165, (b) Size/ Concentration DB 165 and (c) Time/ Concentration DB 165.

\section{matrix}

Experimental design techniques-Doehlert

The Doehlert design is a response surface methodology based on multivariate optimization of variables ${ }^{17}$. The statistical design of adsorption of DB 79 and DB 165 by HAP was used to determine the optimum condition for the removal efficiency for both dyes by HAP, which was done using the Doehlert design ${ }^{18}$. The aim of this step was to determine the best conditions for the adsorption of DB 79 and DB 165 by HAP, the adsorbent concentration was fixed at the high value $(5 \mathrm{~g} / \mathrm{L})$ per $100 \mathrm{ml}$ of solution and size granulometry was fixed at $125 \mu \mathrm{m}$. This study was performed to focus on the predominant factors: the 
concentration of dyes and contact time, in the domain described in Table 3 . The matrix and corresponding code were given in Table 4.
According to the methodology of Doehlert matrix, a second order polynomial response equation was used to correlate the response and independent variables:

$$
\mathrm{Y}=\mathrm{b}_{0}+\sum_{i=1}^{n} b_{i} X_{i}+\sum_{i=1}^{n} b_{i i} X_{i}^{2}+\sum_{\substack{1 \leq i \leq n-1 \\ i+1<j<n}} b_{i j} X_{i} X_{j}
$$

Where $Y$ was the percentage removal of dye, $b_{0}$, $b_{i}, \quad b_{i i}, \quad b_{i j}$ were the constant coefficients and $X_{i, j}$ independent variables ${ }^{19}$. Statistical analyses were performed using nemrodw 2000. Two responses (the yield $\left(\mathrm{Y}_{1}\right)$, the percentage removal of DB 79 and $\left(\mathrm{Y}_{2}\right)$, the percentage removal of DB 165 were studied and simultaneously optimized as described in Table 3.

Table 3. Independent variables and levels used in Doehlert's matrix.

\begin{tabular}{|c|c|c|}
\hline \multicolumn{3}{|c|}{ Levels } \\
\hline Factors & Low (-) & $\operatorname{High}(+)$ \\
\hline $\mathrm{X}_{1} \quad$ Dye concentration $(\mathrm{mg} / \mathrm{L})$ & 20 & 100 \\
\hline $\mathbf{X}_{2} \quad$ Time (min) & 6 & 40 \\
\hline
\end{tabular}

Table 4. Doehlert's experimental design, experimental conditions and responses $\mathrm{Y}_{1}$ : \% Removal of DB 79 and $\mathrm{Y}_{2}$ : $\%$ Removal of DB 165.

\begin{tabular}{|c|c|c|c|c|}
\hline & $\begin{array}{c}\text { Dye concentration } \\
\mathbf{m g} / \mathbf{L}\end{array}$ & $\begin{array}{c}\text { Time } \\
(\mathbf{m i n})\end{array}$ & $\begin{array}{c}\text { \% Y } \\
\text { \%emoval of }\end{array}$ & $\begin{array}{c}\text { \% } \mathbf{2} \\
\text { \%emoval of }\end{array}$ \\
\hline $\mathbf{1}$ & 100 & 23 & 55 & 58 \\
\hline $\mathbf{2}$ & 20 & 23 & 97 & 99 \\
\hline $\mathbf{3}$ & 80 & 38 & 97 & 57 \\
\hline $\mathbf{4}$ & 40 & 8 & 55 & 31 \\
\hline $\mathbf{6}$ & 80 & 8 & 37 & 99 \\
\hline $\mathbf{7}$ & 40 & 38 & 97 & 96 \\
\hline $\mathbf{8}$ & 60 & 23 & 94 & 97 \\
\hline $\mathbf{9}$ & 60 & 23 & 95 & 96 \\
\hline $\mathbf{1 0}$ & 60 & 23 & 94 & 98 \\
\hline $\mathbf{1 1}$ & 60 & 23 & 95 & 96 \\
\hline
\end{tabular}

\section{Variables optimization}

Removal of DB 79

The removal of DB 79 using HAP has been followed using UV-vis spectrophotometer. The analysis of this response (Table 4 and Fig. 7) showed that the percentage of DB $79\left(\mathrm{Y}_{1}\right)$ varies between 73 and $97 \%$. The DB 79 adsorption $\left(\mathrm{Y}_{1}\right)$ can be described as follows:

$$
\mathrm{Y}=94.3-17 * \mathrm{X}_{1}+28.9 * \mathrm{X}_{2}-18.3 *\left(\mathrm{X}_{1} * \mathrm{X}_{1}\right)-23.4 *\left(\mathrm{X}_{2} * \mathrm{X}_{2}\right)+10.2 *\left(\mathrm{X}_{1} * \mathrm{X}_{2}\right)
$$

The correlation coefficient calculated by the model is adequate (i.e. $\mathrm{R}^{2}=0.981$ for $\mathrm{DB} 79$, and $\mathrm{R}^{2} \mathrm{~A}$ $=0.965$ for DB165 respectively). The contact time is the principal factor influencing in adsorption of DB 79 by HAP; when the contact time increases, the DB 79 removal increases (Fig. 7). To maximize the adsorption of DB 79 by HAP, the contact time

between the adsorbent and the adsorbate must increase. The best performances were obtained, close to the central point, $X_{1}(-1)$ and $X_{2}(+1)$. In particular, low removal efficiencies were obtained for high concentration of DB $79\left(\mathrm{X}_{1}=+1\right)$ and low contact time $\left(\mathrm{X}_{2}=-1\right)$. 

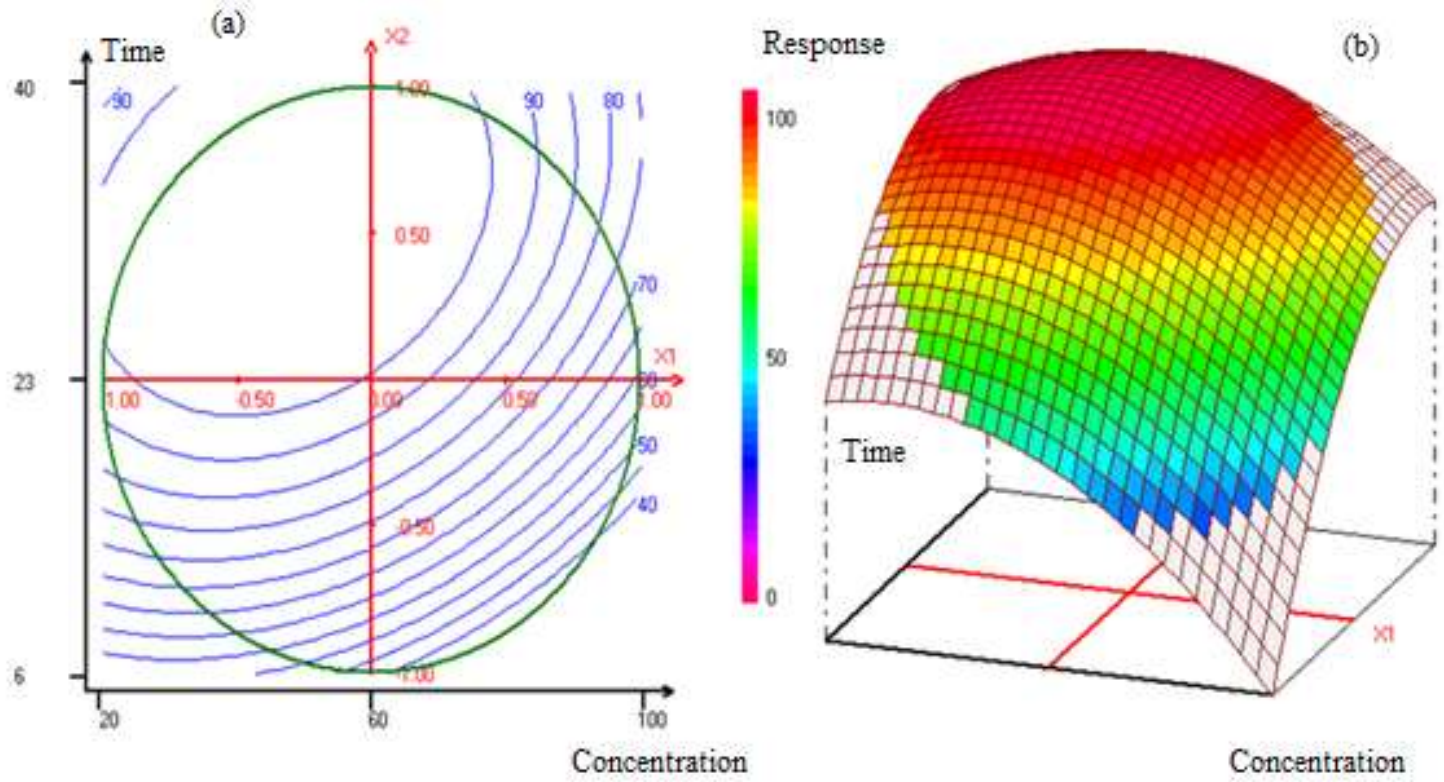

Figure 7. Variation of total yield $\left(\mathrm{Y}_{1}, \%\right)$, of time as a function of concentration of DB 79: (a) 2D, (b) 3D

\section{Removal of DB 165}

Fig. 8 displays the dependence of the \% removal of DB 165 as a function of contact time and DB 165 concentration. The removal \% of DB 165 was only slightly affected by DB 165 concentration with a minimum in the central point of the domain $\left(\mathrm{X}_{3}=0\right)$. On the contrary, the adsorption of DB 165 was significantly influenced by the effect of contact time. The higher removal efficiency was obtained by increasing contact time between the HAP and DB165.

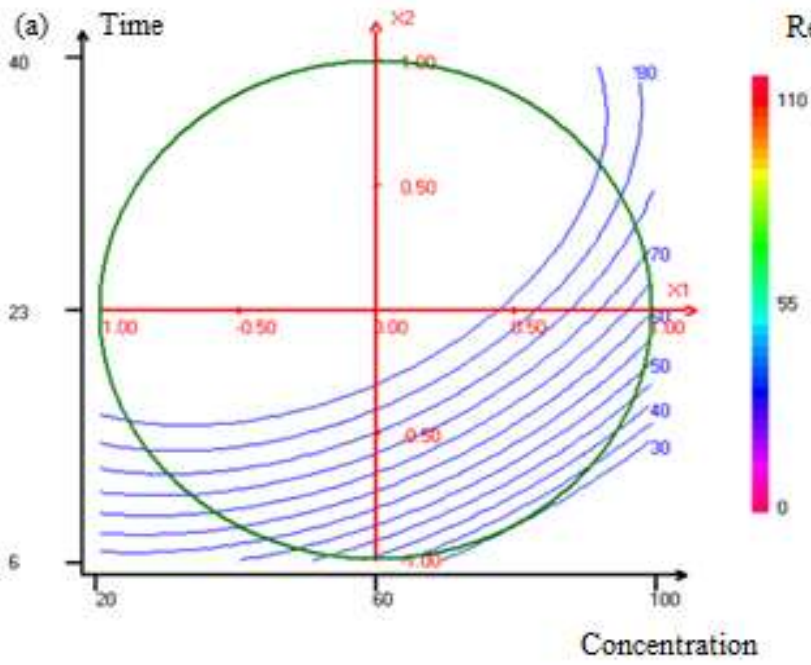

Response

(b)

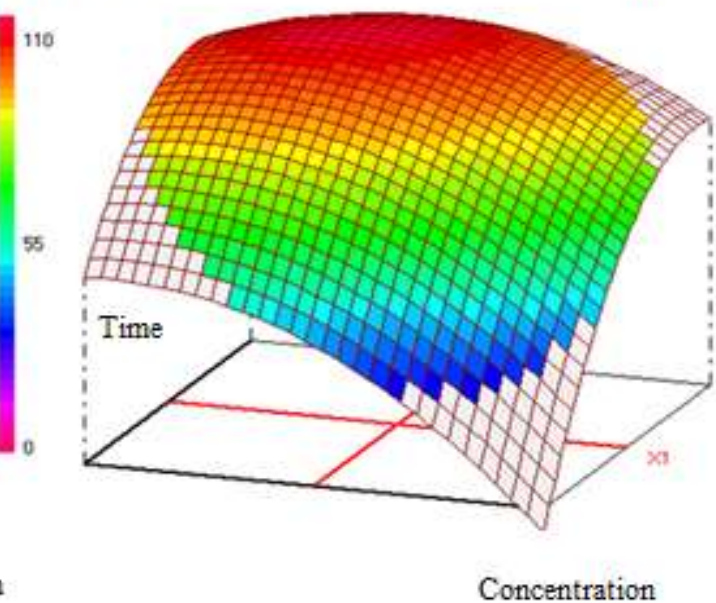

Figure 8. Variation of total yield $\left(\mathrm{Y}_{2}, \%\right)$, of time as a function of concentration of DB 165: (a) 2D, (b) 3D

\section{Comparison of contact time for adsorption of various dyes using hydroxyapatite}

The optimum contact time for the adsorption of various dyes using hydroxyapatite prepared from different synthesis method is presented in Table 5. A comparison between this work and other reported data from the literature shows that synthesis of HAP can be done by various techniques using different reactants and production routes that can modify its physicochemical properties, morphology, chemical composition homogeneity, particle sizes, and degree of crystallinity. Hence, different contact time of adsorption and different removal uptake can be registered, in our work, HAP was prepared using a low-cost method with satisfactory results on removing disperse dyes. 
Table 5. The optimum contact time to reach equilibrium for the adsorption of various dyes using hydroxyapatite as an adsorbent.

\begin{tabular}{|c|c|c|c|c|c|}
\hline $\begin{array}{l}\text { Adsorbent } \\
\text { concentration }\end{array}$ & dye & $\begin{array}{l}\text { Concentration } \\
\text { of Dye }\end{array}$ & $\begin{array}{l}\text { Equilibrium } \\
\text { Time (min) }\end{array}$ & $\begin{array}{l}\% \\
\text { Removal }\end{array}$ & Reference \\
\hline $0.5 \mathrm{~g} / \mathrm{L}$ & Disperse Blue & $20 \mathrm{mg} / \mathrm{L}$ & $30 \mathrm{~min}$ & $100 \%$ & 20 \\
\hline $2 \mathrm{~g} / \mathrm{L}$ & Congo Red & $100 \mathrm{mg} / \mathrm{L}$ & $30 \mathrm{~min}$ & $98.43 \%$ & 21 \\
\hline $2 \mathrm{~g} / \mathrm{L}$ & Congo Red & $50 \mathrm{mg} / \mathrm{L}$ & $10 \mathrm{~min}$ & $99 \%$ & 22 \\
\hline $0.125 \mathrm{~g} / \mathrm{L}$ & $\begin{array}{l}\text { *Methylene } \\
\text { Blue } \\
\text { *Methylene } \\
\text { Orange } \\
\text { *Congo Red }\end{array}$ & $\begin{array}{l}* 50 \mathrm{mg} / \mathrm{L} \\
* 50 \mathrm{mg} / \mathrm{L} \\
* 50 \mathrm{mg} / \mathrm{L}\end{array}$ & $\begin{array}{l}* 5 \mathrm{~min} \\
* 5 \mathrm{~min} \\
* 5 \mathrm{~min}\end{array}$ & $\begin{array}{l}\text { Reach } \\
\text { equilibrium }\end{array}$ & 23 \\
\hline $5 \mathrm{~g} / \mathrm{L}$ & $\begin{array}{l}\text { *Disperse } \\
\text { Blue } 79 \\
\text { *Disperse } \\
\text { Blue } 165\end{array}$ & $\begin{array}{l}* 60 \mathrm{mg} / \mathrm{L} \\
* 60 \mathrm{mg} / \mathrm{L}\end{array}$ & $\begin{array}{l}* 23 \mathrm{~min} \\
* 23 \mathrm{~min}\end{array}$ & $\begin{array}{l}* 94 \% \\
* 98 \%\end{array}$ & This study \\
\hline
\end{tabular}

\section{Conclusion}

The adsorption of DB 79 and DB 165 using hydroxyapatite prepared from phosphogypsum has been studied. The full factorial design applied allowed the evaluation of the most important factors for the removal of DB 79 and DB165. The main conclusions that can be drawn from this study are given below:

- $\quad$ Analysis of different effects of factors (contact time, size, initial dye concentration and adsorbent concentration) shows that the most influential factors, on the yield of removal of DB 79 and DB 165 , are contact time and initial dye concentration.

- Response Surface Methodology was used to determine the acceptable compromise zone for responses of adsorption of DB 79 and DB 165 by hydroxyapatite. The optimal conditions were identified the time at 23 min and 60 initial DB 79 and DB 165 concentrations. At these conditions, the removal percentage of DB 79 and DB 165 were 94 and $98 \%$, respective.

\section{References}

1. H. Keharia, D. Madamwar, Bioremediation concepts for the treatment of dye containing wastewater: a review, Indian Journal of Experimental Biology, 2003, 41, 1068-1075.

2. H. Farajnezhad, P. Gharbani, Coagulation treatment of waste water in petroleum industry using poly aluminum chloride and ferric chloride, IJRRAS. 2012,13-1-25.

3. H. Arroub, A. El Harfi, Modeling and optimization of experimental parameters in the treatment of effluents by coagulation-flocculation processes: Methodology of experimental design, Mediterr. J. Chem., 2018, 7, 183-197.
4. N. Oubagha, W. Lemlikchi, P. Sharrock, M. Fiallo, M. O. Mecherri, Hydroxyapatite precipitation with Hydron Blue dye, Journal of Environmental Management 2016, 1, 1-4.

5. A. Dabrowski, Adsorption from theory to practice, Adv. Colloid Interf. Sci., 2001,93, 135-224.

6. L. Kadiri, A. Ouass, Y. Essaadaoui, H. Rifi and A. Lebkiri, Coriandrum Sativum seeds as a green low-cost biosorbent for methylene blue dye removal from aqueous solution: spectroscopic, kinetic and thermodynamic studies, Mediterr.J.Chem., 2018, 7, 204-216

7. Z. Biyiklioglu, T. Keles, Synthesis and electrochemical characterization of BODIPY dyes bearing polymerizable substituents, Inorganica Chimica Acta, 2017, 466, 130-138

8. E. Hu, S. Shang, X.M. Tao, S. Jiang, K.L. Chiu, Regeneration and reuse of highly polluting textile dyeing effluents through catalytic ozonation with carbon aerogel catalysts, Journal of Cleaner Production, 2016,137, 1055-1065.

9. N. Nikooe, E. Saljoughi, Preparation and characterization of novel PVDF nanofiltration membranes with hydrophilic property for filtration of dye aqueous solution, Applied Surface Science, 2017, 413, 41-49.

10. S. Kumari, R. Naraian, Decolorization of synthetic brilliant green carpet industry dye through fungal co-culture technology, Journal of Environmental Management, 2016,180, 172-179.

11. A. Chennah, Y. Naciri, H. Ait Ahsaine, A. Taoufyq, B. Bakiz, L. Bazzi, F. Guinneton, J.R. Gavarri, A. Benlhachemi, Electrocatalytic properties of hydroxyapatite thin films electrodeposited on stainless steel substrates, Mediterr.J.Chem., 2018, 6, 255-266.

12. H. Nasrellah, A. Loudiki, L. El Gaini, J. El Hajri, M. El Krati, K. Benkhouja, M. Bakasse, 
Process for purifying Moroccan phosphogypsum by a combined sulfuric acid and aluminum salt treatment, Journal phys. chem. news, 2014,74, 76-84.

13. H. Nasrellah, I. Yassine, B. Hatimi, M. Joudi, A. Chemaa, L.El Gaini, Z. Hatim, M.A. El Mhammedi, M. Bakasse, New synthesis of hydroxyapatite from local phosphogypsum, J. Mater. Environ. Sci., 2017, 83, 168-3174.

14. B. El Hilal, A. El Harfi, Radioactive wastes Conditioning: Optimization of operating parameters by experience plan method, Mediterr.J.Chem., 2016, 5, 367-373.

15. D. Mathieu, J. Mony and R. Pan-Tan-Luu, Laboratoire réactionnelle et d'analyse de l'information, Nemrodw, Aix en Provence, France, 2000.

16. N. Barka, S. Qourzal, A. Assabbane, A. Nounah, Y. Ait-Ichou, Removal of Reactive Yellow 84 from aqueous solutions by adsorption onto hydroxyapatite, Journal of Saudi Chemical Society, 2011, 15, 263-267.

17. Y. Zargouni, W. Sassi, K. Alouani, Corrosion Inhibition of AISI 316L and Modified-AISI 630 Stainless Steel by the New Organic Inhibitor [(CH3)2N]3PSe in Chloride Media: Electrochemical and Physical Study, Mediterr.J.Chem.., 2015, 4, 105-110.

18. A.M. Candela, J. Coello, C. Pallet, Doehlert experimental design as a tool to study liquid- liquid systems for the recovery of Uranium (VI) traces.Sep.Purif. Technol., 2013, 118, 339-405.

19. L.F.S. Caldas, C.E.R. Paula, D.M. Brum, R.J. Cassella, Application of a fourvariables Doehlert design for the multivariate optimization of copper determination in petroleum-derived insulating oils by GFAAS employing the dilute-and-shot approach, Fuel, 2013,105, 503-511.

20. N. Barka, S. Qourzal, A. Assabbane, A. Nounah, Y. Ait-Ichou, Adsorption of Disperse Blue SBL dye by synthesized poorly crystalline Hydroxyapatite, Journal of Environmental Sciences 2008, 20, 1268-1272

21. M. Chahkandi, Mechanism of Congo red adsorption on new sol-gel-derived hydroxyapatite nano-particle, Materials Chemistry and Physics, 2017, 202, 340-351.

22. S. M. Parbhua, A. Khana, M. H. Farzanad, G. C. Hwanga, W. Leee, G. Leea, Synthesis and characterization of graphene oxide-doped nanohydroxyapatite and its adsorption performance of toxic diazo dyes from aqueous solution, Journal of Molecular Liquids, 2018, 269, 746-754.

23. Y. Guana, W. Caoa, H. Guana, X. Lei, X. Wang, Y. Tub, A. Marchettia, X. Kong, A novel polyalcohol- coated hydroxyapatite for the fast adsorption of organic dyes, Colloids and Surfaces A, 2018, 548, 85-91. 